\title{
Acute Hypoxia-Reperfusion Triggers Immunocompromise in Nile Tilapia
}

\author{
K. Choi And D. W. Lehmann \\ Department of Environmental and Molecular Toxicology, North Carolina State University, \\ Raleigh, North Carolina 27695, USA \\ C. A. Harms \\ Department of Clinical Sciences, College of Veterinary Medicine, North Carolina State University, \\ Raleigh, North Carolina 27606, USA
}

J. M. LAW*

Department of Population Health and Pathobiology, College of Veterinary Medicine, North Carolina State University, Raleigh, North Carolina 27606, USA

\begin{abstract}
Inadequate dissolved oxygen in the aquatic environment is a well-established cause of fish morbidity and mortality. The specific effects of hypoxia on immune function in fish, however, are not well characterized. In this study, the effects of acute hypoxia followed by reoxygenation (rapid tissue reperfusion) as a source of immunocompromise in Nile tilapia Oreochromis niloticus were investigated. Using a precision apparatus developed in our laboratory for hypoxia exposures, a series of assays of increasing specificity for immune function were performed on acutely hypoxia-stressed Nile tilapia: tier I consisted of histopathology, tier II of hematology, plasma chemistry, and determining cortisol concentration, and tier III of determining the phagocytic index and analyzing the expression of the cytokines transforming growth factor- $\beta$ (TGF- $\beta$ ) and interleukin-1 $\beta$ (IL-1 $\beta$ ). Nile tilapia were exposed to $7 \%$ oxygen saturation for $96 \mathrm{~h}$, then tank water was rapidly reoxygenated. Sampling intervals were 48 and $96 \mathrm{~h}$ during hypoxia and 12 and $84 \mathrm{~h}$ during reperfusion. Histopathology showed no remarkable microscopic abnormalities in lymphoid or other tissues. Lymphopenia and neutrophilia were observed in peripheral blood. Plasma total protein, partial pressure of oxygen, and oxygen saturation were decreased in response to hypoxia. Plasma lipase decreased in response to hypoxia but returned to normal during reperfusion. Phagocytic capability and the phagocytic index decreased during hypoxia and $12 \mathrm{~h}$ reperfusion, whereas these values were recovered by $84 \mathrm{~h}$ reperfusion. The TGF- $\beta$ transcription continued to increase during the exposures, the greatest production being at $12 \mathrm{~h}$ reperfusion, whereas IL-1 $\beta$ transcription decreased in response to hypoxia and reperfusion. We conclude that acute hypoxia triggered an overall downregulation of the immune system in the test fish. This suggests a possible factor in the pathogenesis of disease outbreaks in fish in which repeated, sublethal bouts of environmentally induced hypoxia lead to increased disease susceptibility and individual mortalities rather than massive fish kills.
\end{abstract}

It is axiomatic that lack of oxygen leads to the injury and death of cells and tissues and, thus, of whole organisms. Fish are especially vulnerable to hypoxia since water contains only a small amount of oxygen for respiration (Boyd 1990). While many fish kill events have been attributed to low dissolved oxygen (DO), the sublethal effects of hypoxia are less understood. Relatively little is known about the particular effects of hypoxia on immune function in fish and, by extension, its role in disease pathogenesis.

During the last two decades, U.S. mid-Atlantic estuaries have been plagued by large-scale fish kills, often accompanied by outbreaks of ulcerative skin

\section{* Corresponding author: mac_law@ncsu.edu}

Received February 3, 2006; accepted November 15, 2006 Published online June 18, 2007 lesions (NCDENR 1997, 2000; Dykstra 2000). Recent studies have demonstrated the potential roles of microbial pathogens in these epizootics, including oomycetes (fungi), such as Aphanomyces invadans, and blooms of harmful algae, such as Pfiesteria spp. (Noga et al. 1996; Noga 2000; Blazer et al. 2002; Kiryu et al. 2002). It has become apparent that the pathogenesis of these lesion outbreaks is multifactorial and both geographically and seasonally variable. Since the role of sudden changes in water quality parameters in disease pathogenesis is less clear, the objective of this study was to determine the effects of acute hypoxia and rapid reoxygenation (reperfusion) on the immune system of fish. "Acute" hypoxia was operationally defined here as $96 \mathrm{~h}$ continuous exposure to sublethal low DO concentration to distinguish from the more chronic hypoxia exposures in the current literature lasting multiple weeks. 
Adverse water quality in terms of anthropogenic activity or adverse environmental conditions, such as hypoxia, temperature and salinity changes, and sediment influx, may induce compromise of the immune system, leading to lowered resistance to pathogen invasion (Adams et al. 1989; Anderson and Zeeman 1995; Bly et al. 1997). Seasonal and diurnal hypoxia or anoxia has been commonly found in estuarine and coastal marine waters (Turner and Allen 1972; Harper et al. 1981) associated with mass mortality of benthic organisms and fish throughout large marine coastal areas (Wu 2002). Low DO has worsened as a result of agricultural runoff, vertical stratification, and salinity influx (Turner et al. 1987; Malone 1991; Paerl et al. 2001). Hypoxia has been shown to modulate the innate and adaptive immune responses in fish (Bunch and Bejerano 1997; Boleza et al. 2001; Cecchini and Saroglia 2002; Ortuno et al. 2002; Cuesta et al. 2003; Woo 2003). For example, recent reports have demonstrated high mortality as a result of streptococcal infection in tilapia Oreochromis spp. exposed to hypoxic conditions (Bunch and Bejerano 1997; Evans et al. 2003). Low DO both shortened the incubation period for infection and increased the cumulative mortality in yellowtail jacks Seriola lalandi challenged with Enterococcus seriolicida (Fukuda et al. 1997). Cecchini and Saroglia (2002) demonstrated that antibody responses against human gamma globulin in hypoxic European sea bass Dicentrarchus labrax (also known as European bass Morone labrax) were weaker than those in hyperoxic European sea bass. Air exposure-induced hypoxia reduced the respiratory burst in gilthead seabream (also known as gilthead bream) Sparus auratus (Ortuno et al. 2002) and also inhibited head kidney natural cytotoxic cell activity of gilthead seabream (Cuesta et al. 2003).

In response to acute hypoxia, systemic responses are triggered, such as increased ventilation and cardiac output followed by tissue or cell anaerobic metabolism, whereas for chronic hypoxia, molecular changes occur in terms of upregulated gene expression to increase oxygen transport capacity and capillary blood supply (Michiels 2004). In both mammals and fish, hypoxiainducible factor-1 alpha (HIF-1 $\alpha$ ), a heterodimeric transcription factor, is upregulated in response to hypoxia and regulates hypoxia-inducible genes involved in erythropoiesis, glycolysis, and angiogenesis (Wu 2002). Chronic hypoxia also interferes with the reproductive system, resulting in endocrine disruption of common carp Cyprinus carpio (Wu et al. 2003). Hypoxia followed by reperfusion can damage tissue more than hypoxia alone as a result of an overload of free radicals, excess cytosolic $\mathrm{Ca}^{+}$, and modulation of cytokines, such as transforming growth factor- $\beta$ (TGF- $\beta$ ), interleukin-1 (IL-1), and other proinflammatory components (Jordan et al. 1999; Yellon and Baxter 1999; Chen 2003).

The TGF- $\beta$ is an immunoregulatory, primarily suppressive cytokine that also influences cell proliferation and differentiation, extracellular matrix regulation, wound healing, angiogenesis, apoptosis, production of cytokines, and lipid metabolism (Zhang and Phan 1999; Harms et al. 2000; Zuckerman et al. 2001). There is some evidence that TGF- $\beta_{1}$ is involved in hypoxia-reperfusion injury in mammals (Basile et al. 1998; Dhandapani and Brann 2003). In general, upregulation of TGF- $\beta$ expression is associated with fibrosis and atrophy of renal function in hypoxiareperfusion injury (Basile et al. 1998), whereas it contributes to neuroprotective factor in cerebral ischemia (Dhandapani and Brann 2003). The IL-1 is a polypeptide proinflammatory cytokine that is a potent inducer of acute phase responses and inflammation and a signaling molecule between the immune system and other body systems, such as the hypothalamuspituitary-adrenal axis in mammals (Rosenwasser 1998; Engelsma et al. 2001). Hypoxia increases the lipopolysaccharide (LPS)-stimulated release of IL-1 in human alveolar macrophages (Hempel et al. 1996). The IL-1-like factor is found in common carp and other fish , and its bioactivity, along with induction of IL-1 $\beta$ transcript by stimulation with LPS or challenge with bacteria, is similar to that in mammals (Secombes et al. 1999). However, the effects of hypoxia on IL-1 in fish have not been reported.

To address our hypothesis that acute hypoxia may lead to immunosuppression in fish, thus increasing their susceptibility to disease, we used the tilapia model under controlled laboratory conditions. The Nile tilapia $O$. niloticus is a well-known freshwater teleost and has been used in numerous laboratory studies because of its hardiness in captivity and resistance to varying environmental stressors (Verdegem et al. 1997). Our endpoints were a series of bioassays grouped into three "tiers" of increasing specificity for immune function and performed on hypoxia-stressed Nile tilapia: tier I consisted of histopathology, tier II of hematology and plasma chemistry, and tier III of determining the phagocytic index and analyzing the expression of the cytokines TGF- $\beta$ and IL-1 $\beta$.

\section{Methods}

Laboratory-reared 6-month-old Nile tilapia of mixed sexes and weighing $235 \pm 30 \mathrm{~g}$ were obtained from the North Carolina State University (NCSU) Aquaculture Facility. The fish were acclimated in a 756-L tank for 1 week in constantly aerated, filtered, dechlorinated water at $25 \pm 0.5^{\circ} \mathrm{C}$ and kept on a 16-h-light: 8-h-dark 
photoperiod. Water conditions were as follows: $\mathrm{pH} 7.0$ \pm 0.5 ; ammonia, less than $0.25 \mathrm{mg} / \mathrm{L}$; nitrate, less than $20 \mathrm{mg} / \mathrm{L}$; and nitrite, less than $2 \mathrm{mg} / \mathrm{L}$. Fifty percent of the tank water was replaced on alternate days. The fish were fed a commercial food (Ziegler Bros., Gardners, Pennsylvania) ad libitum; feeding was suspended $24 \mathrm{~h}$ before the experiment and restarted after restoring normoxic conditions. The fish were randomized into 20 fish/tank (treatment and control tanks), and the experiments were carried out in duplicate.

In a preliminary study, we were unable to calculate a median lethal concentration value for hypoxia at $2 \mathrm{~h}$ owing to the Nile tilapia's hypoxia tolerance. Survival curves showed a $25 \%$ mortality rate at $3 \%(0.24 \mathrm{mg} / \mathrm{L})$ saturation levels and $0 \%$ mortality at $7 \%(0.57 \mathrm{mg} / \mathrm{L})$ saturation levels. Based on these data, we chose $7 \%$ DO saturation for the definitive experiment to achieve an effective, yet nonlethal DO concentration. Fish $(n=$ 20) were exposed to $7 \%$ DO saturation for $96 \mathrm{~h}$ followed by $84 \mathrm{~h}$ of normoxic conditions that were maintained by heavy aeration of the holding tank; this heavy aeration achieved approximately $97 \%$ oxygen saturation. An $\mathrm{N}_{2}$ gas was used to create the hypoxic conditions as previously described (Lehmann et al. 2005). Briefly, a DO electrode was placed in the treatment tank and oxygen level was maintained by opening or closing a solenoid connected to the $\mathrm{N}_{2}$ source. The oxygen concentration in the tank was controlled uniformly by a digital controller continuously monitoring oxygen concentrations and turning a gas exchange unit on as necessary. To ensure that the fish were not gasping at the surface to artificially increase oxygen uptake, the tank was covered with clear vinyl sheeting during the exposure. Tank water $\mathrm{pH}$ was monitored throughout the experiments and did not change significantly. Control groups $(n=20)$ were kept at normoxic conditions throughout the experiments $(97 \%$ oxygen saturation averaging $8.2 \pm 0.15$ $\mathrm{mg} / \mathrm{L} \mathrm{DO}$ at $25 \pm 0.5^{\circ} \mathrm{C}$ ).

Sampling was performed at 48 and $96 \mathrm{~h}$ during hypoxia and at 12 and $84 \mathrm{~h}$ after reperfusion (operationally defined in this study as rapid restoration of normoxia after hypoxic treatment). Five fish from each group were collected at each time point and anesthetized with $150 \mathrm{mg} / \mathrm{L}$ tricaine methanesulfonate (MS-222; Sigma-Aldrich Co., St. Louis, Missouri). Blood samples were collected from the caudal vein in an untreated syringe, and an i-STAT portable clinical analyzer (Abbott Laboratories, East Windsor, New Jersey) was used to determine clinical blood parameters. Immediately after the first draw, a second heparinized syringe was used to draw as much blood as possible (to deplete the spleen of interfering erythrocytes during in vitro culture) and stored at room temperature until used for collection of leukocytes. Each spleen was removed aseptically and placed in complete RPMI medium (all reagents from Thermo Fisher Scientific, Waltham, Massachusetts, unless otherwise specified) supplemented with $10 \%$ heatinactivated fetal bovine serum, $100 \mathrm{U} / \mathrm{mL}$ penicillin, $100 \mathrm{~g} / \mathrm{mL}$ streptomycin, and $2 \mathrm{mM}$ EDTA. The whole blood was diluted 1:1 in phosphate-buffered saline (PBS) at room temperature and centrifuged at $400 \times$ gravity $(g)$ for $5 \mathrm{~min}$. The buffy coat layer was harvested, resuspended in 1\% PBS, and placed on a $55 \%$ Percoll gradient (specific gravity $=1.0697 \mathrm{~g} / \mathrm{mL}$ ) at $800 \times g$ for $30 \mathrm{~min}$ at $16^{\circ} \mathrm{C}$. The peripheral blood leukocyte (PBL) band was harvested, washed three times in complete RPMI-1640, and counted and adjusted to a cell density of $1 \times 10^{6}$ cells $/ \mathrm{mL}$. Isolation of splenic leukocytes was performed as described by Harms et al. (2000). Briefly, the spleen was finely minced, forced through a wire mesh, and resuspended in complete RPMI. The cell suspension was placed on a two-step Percoll gradient at $400 \times g$ for $5 \mathrm{~min}$ (specific gravity $=1.052 \mathrm{~g} / \mathrm{mL}$ ) and then $800 \times g$ for 25 $\min$ (specific gravity $=1.065 \mathrm{~g} / \mathrm{mL}$ ). Splenic leukocytes in the interface were harvested, counted, and adjusted to a cell density of $1 \times 10^{7}$ cells $/ \mathrm{mL}$. Cell viability assessment was performed in $0.2 \%$ trypan blue.

\section{Tier I: Histopathology}

All fish were necropsied. Samples of anterior kidney, gill, intestine, heart, and liver were fixed in $10 \%$ neutral-buffered formalin, routinely processed, embedded in paraffin, sectioned at $5 \mu$, stained with hematoxylin and eosin, and examined via light microscopy by a single pathologist. The following six-point grading scale was used for evaluation: grade 0 , no remarkable microscopic abnormalities; grade 1 , very mild changes; grade 2, mild changes; grade 3, moderate; grade 4, moderately severe; and grade 5 , the most severe changes for a given lesion type (Hurty et al. 2002).

\section{Tier II: Blood Parameters}

Plasma chemistry.-Blood samples were analyzed with a Hitachi 717 chemical analyzer (F. Hoffmann-La Roche, Ltd.,, Basel, Switzerland) by Antech Diagnostics, Inc., (Cary, North Carolina) for glucose, urea nitrogen, creatinine, cholesterol, triglyceride, lipase (enzyme number 3.1.1.3; IUBMB 1992), total protein, alkaline phosphatase (3.1.3.1), alanine aminotransferase (2.6.1.2), aspartate aminotransferase (2.6.1.1), calcium $(\mathrm{Ca})$, phosphorus $(\mathrm{P})$, chloride $(\mathrm{Cl})$, and magnesium $(\mathrm{Mg})$. Sodium $(\mathrm{Na})$, potassium $(\mathrm{K})$, ionized $\mathrm{Ca}(\mathrm{iCa})$, hematocrit (Hct), $\mathrm{pH}$, partial pressure of 
carbon dioxide $\left(\mathrm{PCO}_{2}\right)$, partial pressure of oxygen $\left(\mathrm{Po}_{2}\right)$, bicarbonate $\left(\mathrm{HCO}_{3}\right)$, oxygen saturation $\left(\mathrm{So}_{2}\right)$, and hemoglobin $(\mathrm{Hb})$ were measured with the i-STAT portable clinical analyzer.

Differential blood cell counts.-Blood smears from each fish were stained with Wright's Giemsa and examined by light microscopy under oil immersion (100× objective). One hundred leukocytes were counted in each smear and categorized into lymphocytes, monocytes-macrophages, or neutrophils.

Cortisol.-Whole blood was centrifuged at 10,000 $\times$ $g$ for $10 \mathrm{~min}$ and plasma was harvested and kept at $-80^{\circ} \mathrm{C}$ until analysis. Plasma cortisol was measured with the IMMULITE chemiluminescent immunoassay (Diagnostic Products Corporation, Los Angeles, California) by the Clinical Pharmacology Laboratory, NCSU College of Veterinary Medicine.

\section{Tier III: Immune Function Assays}

Phagocytosis.-The in vitro phagocytic assay was a modification of that described for phagocytic cells in blood from rainbow trout Oncorhynchus mykiss (Thuvander et al. 1987). Peripheral blood leukocytes of Nile tilapia were isolated as described above. The PBL suspensions $\left(1 \times 10^{6}\right.$ cells $\left./ \mathrm{mL}\right)$ were cultured in 6-well flat-bottom tissue culture plates with fluorescein isothiocyanated (FITC), 1.75- $\mu \mathrm{m}$-diameter latex beads (Polysciences, Northampton, UK) in 5\% $\mathrm{CO}_{2} / 95 \%$ air in a humidified incubator for $5 \mathrm{~h}$ at $26^{\circ} \mathrm{C}$. To opsonize the beads, the latex beads were incubated with newborn calf serum for $30 \mathrm{~min}$ at $37^{\circ} \mathrm{C}$, washed with cold PBS two times, and stored at $4^{\circ} \mathrm{C}$ until use. Before use, opsonized beads were washed twice in PBS and sonicated for $15 \mathrm{~min}$ to resuspend aggregated beads. The cell\&hairsp: bead ratio was approximately 1:30. At the end of incubation, $1 \mathrm{~mL}$ of PBS was added to stop phagocytosis followed by centrifugation at $400 \times$ $g$ for $10 \mathrm{~min}$. Pellets were resuspended in $100 \mu \mathrm{L}$ of $1 \%$ PBS. Then, $50 \mu \mathrm{L}$ of $1 \%$ Triton $\mathrm{X}$ and $50 \mu \mathrm{L}$ of propidium iodide $(0.5 \mathrm{mg} / \mathrm{mL}$; F. Hoffmann-La Roche, Ltd.) was added and the samples were analyzed by fluorescence microscopy. At least 100 cells were counted and the percentages of phagocytic cells engulfing latex beads as phagocytic capability were estimated. The phagocytic index (PI) was defined as the average number of ingested latex beads per phagocytic cell. Therefore, the total number of ingested beads was divided by the total number of phagocytic cells.

Expression of TGF- $\beta$ and IL-1 $\beta$ : isolation of total $R N A$ and reverse transcription.-For total RNA isolation, $1 \mathrm{~mL}$ of TRI reagent (Sigma-Aldrich Co.) for each $5-10 \times 10^{6}$ cells was added to each splenic leukocyte pellet, and total RNA was isolated according to manufacturer's instructions. The RNA pellet was resuspended in sterile DNase-RNase-free water (Sigma-Aldrich Co.) at a concentration of $5 \times 10^{4}$ cell equivalents/ $\mu \mathrm{L}$, then 300 pmol oligo $\mathrm{dt}_{15}$ (Promega Corporation, Madison, Wisconsin) for reverse transcription was added to total RNA $\left(3 \times 10^{6}\right.$ cell equivalents) in a $72-\mu \mathrm{L}$ volume, heated at $94^{\circ} \mathrm{C}$ for 5 min, and chilled on ice immediately. Then $78 \mu \mathrm{L}$ of additional RT mixture was mixed in a final volume of $150 \mu \mathrm{L}: 1 \times$ buffer $(50 \mathrm{mM}$ tris- $\mathrm{HCl}, \mathrm{pH} 8.3 ; 75 \mathrm{mM}$ $\mathrm{KCl} ; 3 \mathrm{mM} \mathrm{MgCl} 2), 0.4 \mathrm{mM}$ each deoxynucleotide triphosphate (dNTP), $10 \mathrm{mM}$ DTT, $0.8 \mathrm{U} / \mu \mathrm{L}$ RNAsin, and $2 \mathrm{U} / \mu \mathrm{L}$ reverse transcriptase (SuperScript II RT; Invitrogen Corporation, Gaithersburg, Maryland). Sample cDNA was transcribed at $45^{\circ} \mathrm{C}$ for $60 \mathrm{~min}$, chilled on ice, and diluted 1:2 in sterile DNase-RNasefree water and stored at $-20^{\circ} \mathrm{C}$ until analysis.

The TGF- $\beta$ primers of Nile tilapia.-Primers (Con A1 and Con B2; Table 1) against hybrid striped bass (female striped bass Morone saxatilis $\times$ male white bass $M$. chrysops) TGF- $\beta$ were used for initial polymerase chain reaction (PCR; Harms et al. 2000). The cycling protocol consisted 1 cycle of $94^{\circ} \mathrm{C}$ for 1 min; 31 cycles of $94^{\circ} \mathrm{C}$ for $30 \mathrm{~s}$ (denaturing), $57^{\circ} \mathrm{C}$ for $1.5 \mathrm{~min}$ (annealing), and $72^{\circ} \mathrm{C}$ for $2 \mathrm{~min}$ (extension); and 1 cycle of $72^{\circ} \mathrm{C}$ for $7 \mathrm{~min}$ (final extension). The PCR product was visualized on $1.5 \%$ agarose gels containing ethidium bromide $(0.5 \mathrm{mg} / \mathrm{mL})$ and purified with a gel extraction kit (QIAGEN, Inc., Valencia, California). The DNA amplified by PCR was submitted to the University of North Carolina at Chapel Hill Automated DNA Sequencing Facility. Automated sequencing employed a 373A DNA sequencer (Applied Biosystems, Foster City, California). Sequences generated were analyzed for similarity with other known sequences using BLAST and DNASTAR software. Further primers for real-time PCR (TIF and TIR) were made based on sequences generated above.

Primers for beta-actin were generated as the "housekeeping gene" in the quantitative real-time PCR assay. Beta-actin primers (BacF1 and BacR1) were based on alignment of zebrafish Danio rerio (GenBank accession number AA566386), red seabream Pagrus major (AB036756), rainbow trout (AF254414), grass carp Ctenopharyngodon idella (M25013), common carp (M24113), goldfish Carassius auratus (AB039726), and fugu Takifugu rubripes (U38849) to amplify a 139-base-pair (bp) fragment verified by PCR product size. The sequences of PCR primer pairs are shown in Table 1.

$I L-1 \beta$ cloning and sequencing.-Initial primers (MUF4 and MUR3) were designed against conserved regions from known teleost IL-1 $\beta$ sequences in the GenBank databases. Initial primers were based on 
TABLE 1.-Primers used on hypoxia-stressed Nile tilapia. Targets are transforming growth factor- $\beta$ (TGF- $\beta$ ), beta-actin, and interleukin-1 $\beta$ (IL-1 $\beta$ ); bp = base pairs.

\begin{tabular}{lllc}
\hline Target & Primer & \multicolumn{1}{c}{ Sequences $\left(5^{\prime}-3^{\prime}\right)$} & PCR product size (bp) \\
\hline TGF- $\beta$ & Con A1 & GACCTGGGATGGAAGTGGAT (20 mer) & $300 \mathrm{bp}$ \\
& Con B2 & CAGCTGCTCCACCTTGTGTTG (21 mer) & $114 \mathrm{bp}$ \\
& TIF & TATATCTGGGATGCCGAAAACA (22 mer) & \multirow{2}{*}{$139 \mathrm{bp}$} \\
\multirow{2}{*}{ beta-actin } & TIR & TGGCAGTGGCTCTAGTGTCTGT (22 mer) & \multirow{2}{*}{$324 \mathrm{bp}$} \\
& Bacf1 & TGGCATCACACCTTCTATAACGA (23 mer) & $113 \mathrm{bp}$ \\
& Bacr1 & TGGCAGGAGTGTTGAAGGTCT (21 mer) & \\
& MUF4 & GAGTGTGGTCAACCTCATCAT (21 mer) & \\
& MUR3 & GCTGTGCTGATGTACCAGTTG (21 mer) & \\
& ABF1 & TGCACTGTCACTGACAGCCAA (21 mer) & \\
& ABR1 & ATGTTCAGGTGCACTATGCGG (21 mer) & \\
\hline
\end{tabular}

alignment of gilthead seabream (AJ277166), Japanese flounder (also known as olive flounder) Paralichthys olivaceus (AB070835), and European sea bass (AJ269472). These primers were used for PCR and sequenced as above. The sequenced IL- $1 \beta$ messenger RNA (mRNA) of Nile tilapia was submitted to GenBank (DQ061114). A PCR was performed with cDNA from a range of tissues (spleen, gill, and liver) of Japanese flounder, Nile tilapia, and rainbow trout. Mononuclear cells were isolated, followed by in vitro stimulation with $10 \mu \mathrm{L}$ of LPS $(1 \mathrm{mg} / \mathrm{mL}$; SigmaAldrich Co.) for $4 \mathrm{~h}$ at $26^{\circ} \mathrm{C}$. In vitro stimulation was required to study IL- $1 \beta$ expression since there was no detectable (constitutive) expression in unstimulated fish (Zou 1999). Further primers (ABF1 and ABR1) were designed against initial primer-generated sequences to allow amplification of a 115-bp fragment for real-time PCR. The 115-bp product was cloned with the Taq-amplified (TA) cloning kit (Invitrogen Corporation), and an accurate colony was confirmed by PCR. Plasmid DNA was quantified by VersaFluor fluorometer (Bio-Rad Laboratories, Hercules, California) with the fluorescent DNA quantitation kit (BioRad Laboratories). For each reaction of real-time PCR, four 10-fold serial dilutions of plasmid DNA were used to make standard curves for both target and housekeeping genes.

Real-time quantitative PCR analysis.-Real-time quantitative PCR analysis of TGF- $\beta$ and IL- $1 \beta$ was performed with the iCycler (Bio-Rad Laboratories). The PCR reaction mixtures were $1 \times$ PCR buffer $(50$ $\mathrm{mM}$ tris- $\mathrm{HCl}, \mathrm{pH} 8.3 ; 10 \mathrm{mM} \mathrm{KCl} ; 5 \mathrm{mM}\left[\mathrm{NH}_{4}\right]_{2} \mathrm{SO}_{4}$; and $2 \mathrm{mM} \mathrm{MgCl}{ }_{2}$ [F. Hoffmann-La Roche, Ltd.]), 0.2 mM PCR dNTP mix (F. Hoffmann-La Roche, Ltd.), 5 U/ $\mu \mathrm{L}$ FastStart Taq DNA polymerase (F. HoffmannLa Roche, Ltd.), $1 \times$ SYBR Green (Sigma-Aldrich Co.), and $150 \mathrm{nM}$ of each primer and $5 \mu \mathrm{L}$ cDNA in a final volume of $50 \mu \mathrm{L}$. The cycling protocol consisted of 1 cycle of $95^{\circ} \mathrm{C}$ for $2 \mathrm{~min} ; 31$ cycles of $95^{\circ} \mathrm{C}$ for $30 \mathrm{~s}$ (denaturing), $57^{\circ} \mathrm{C}$ for $30 \mathrm{~s}$ (annealing), and $72^{\circ} \mathrm{C}$ for 2 min (extension); and 1 cycle of $72^{\circ} \mathrm{C}$ for 7 min (final extension). Relative quantitation of the cytokine signal was performed by normalization to the beta-actin signal.

\section{Statistical Methods}

Data were analyzed with the SAS analysis of variance procedure (SAS 2003). Multiple comparisons of means response was performed by least significant difference and Tukey's test with the MEANS and GLM procedures of SAS. Differences were considered significant at $P<0.05$.

\section{Histopathology}

\section{Results}

Complete postmortem examination of each fish in this study, including necropsy and histopathology, revealed no remarkable lesions attributable to hypoxia exposure (data not shown). In addition, there were no remarkable lesions suggesting prior disease conditions or confounding lesions that might mask changes in the spleen, hematopoietic tissue, or other tissues related to the immune system.

Several relatively common, incidental lesions were found in the head kidneys, gills, and livers of both control and treated fish. The head kidneys of nearly all fish contained small numbers of pigmented macrophage aggregates, while two treated fish had a few small granulomas. The gills were generally within normal limits; however, two treated fish had mild thickening of the secondary lamellae. These areas were not associated with any remarkable inflammation in the gills. The livers of four treated and one control fish had very mild to moderate perivascular inflammation, and one fish had a few small hepatic granulomas.

\section{Hematology}

The relative percentage of lymphocytes in peripheral blood significantly decreased during $48 \mathrm{~h}$ and $96 \mathrm{~h}$ hypoxia and $12 \mathrm{~h}$ reperfusion compared with hypoxia 
TABLE 2.-Differential blood cell counts of Nile tilapia $(\mathrm{n}=5)$ subjected to $96 \mathrm{~h}$ of hypoxia followed by $84 \mathrm{~h}$ of reperfusion. Significant differences between control and treatment groups $(P<0.0001)$. A lowercase y or z denotes a significant difference among lymphocyte $(P<0.0001)$ and neutrophil counts $(P<0.03)$ during the experimental procedures. Values are means \pm SEs and sample units are percentages.

\begin{tabular}{|c|c|c|c|c|c|c|c|c|}
\hline \multirow[b]{3}{*}{ Cell type } & \multicolumn{4}{|c|}{ Exposure time } & \multicolumn{4}{|c|}{ Postexposure time } \\
\hline & \multicolumn{2}{|c|}{$48 \mathrm{~h}$} & \multicolumn{2}{|c|}{$96 \mathrm{~h}$} & \multicolumn{2}{|c|}{$12 \mathrm{~h}$} & \multicolumn{2}{|c|}{$84 \mathrm{~h}$} \\
\hline & Control & Treated & Control & Treated & Control & Treated & Control & Treated \\
\hline Lymphocytes & $93.5 \pm 2.1$ & $81.7 \pm 2.6 \mathrm{y}$ & $93.1 \pm 1.8$ & $82.4 \pm 2.5 \mathrm{y}$ & $90.3 \pm 1.4$ & $80.4 \pm 3.3 \mathrm{y}$ & $92.3 \pm 1.7$ & $93.0 \pm 1.9 \mathrm{z}$ \\
\hline Neutrophils & $3.5 \pm 3.2$ & $12.2 \pm 4.1 \mathrm{z}$ & $2.7 \pm 3.0$ & $14.2 \pm 4.9 \mathrm{z}$ & $5.8 \pm 3.8$ & $15.2 \pm 7.9 \mathrm{z}$ & $3.6 \pm 1.9$ & $3.5 \pm 2.8 \mathrm{y}$ \\
\hline
\end{tabular}

$(P=0.0001)$, whereas it returned to the initial control value at $84 \mathrm{~h}$ reperfusion (Table 2 ). The relative percentage of neutrophils increased during $48 \mathrm{~h}$ and 96 $\mathrm{h}$ hypoxia and $12 \mathrm{~h}$ reperfusion, whereas percent neutrophils returned to near the control level at $84 \mathrm{~h}$ reperfusion. Percent monocytes did not significantly change during hypoxia and reperfusion. Hematocrit values (measured as percentage packed cell volume) ranged from $19.8 \%$ to $27.0 \%$ during hypoxia and reperfusion, but did not differ significantly among groups (data not shown).

\section{Plasma Chemistry, Blood Gases, and Cortisol}

There were no significant differences in plasma chemistry, blood gases, or cortisol between control and exposed fish during hypoxia and reperfusion except for $\mathrm{Po}_{2}, \mathrm{So}_{2}$, total protein, and lipase (Table 3). The $\mathrm{PO}_{2}$ and $\mathrm{So}_{2}$ values were significantly lower than those of controls during hypoxia $(P<0.001)$. The $\mathrm{So}_{2}$ was mostly recovered during reoxygenation, whereas $\mathrm{PO}_{2}$ remained low in the treated fish. Total protein in plasma was significantly lower at 96 h hypoxia and 12 $\mathrm{h}$ reperfusion than in the controls, but its value returned to control level at $84 \mathrm{~h}$ reperfusion $(P<0.001)$. At 48 h hypoxia, total protein was observed to be at its lowest level during the experiment $(P<0.05)$. Plasma lipase decreased significantly compared with controls during hypoxia but not reperfusion $(P<0.001)$. However, its value was not significantly different between hypoxia and reperfusion.

\section{Phagocytosis}

Phagocytic capability was significantly different during hypoxia and reperfusion compared with controls, except at $84 \mathrm{~h}$ reperfusion $(P<0.0001$; Figure 1). Its value continuously decreased at $48 \mathrm{~h}$ and $96 \mathrm{~h}$ hypoxia and $12 \mathrm{~h}$ reperfusion but returned to initial control value at $84 \mathrm{~h}$ reperfusion $(P<0.004)$. The numbers of beads phagocytosed by PBL varied during hypoxia and reperfusion (Table 4). The cells with only one bead and with three or more beads were significantly different from controls, except at $84 \mathrm{~h}$ reperfusion $(P<0.0001)$. These values continuously decreased at $48 \mathrm{~h}$ and $96 \mathrm{~h}$ hypoxia and $12 \mathrm{~h}$ reperfusion, but returned to control levels at $84 \mathrm{~h}$ reperfusion $(P<0.007$ and $P<0.05$, respectively). Cells with only two engulfed beads were significantly different from controls at $96 \mathrm{~h}$ hypoxia and $12 \mathrm{~h}$ reperfusion $(P<0.0001)$. This value decreased most significantly at $96 \mathrm{~h}$ hypoxia and returned to the control value at $84 \mathrm{~h}$ reperfusion $(P<0.04)$. The PI was significantly different from controls, except at $84 \mathrm{~h}$

TABLE 3.-Plasma concentration of partial pressure of oxygen $\left(\mathrm{PO}_{2} ; \mathrm{mm} \mathrm{Hg}\right)$, oxygen saturation $\left(\mathrm{So}_{2} ; \%\right)$, partial press of carbon dioxide $\left(\mathrm{PCO}_{2} ; \mathrm{mm} \mathrm{Hg}\right)$, total protein $(\mathrm{g} / \mathrm{dL})$, and lipase $(\mathrm{U} / \mathrm{L})$ of tilapia $(n=5)$ subjected to $96 \mathrm{~h}$ of hypoxia followed by $84 \mathrm{~h}$ of reperfusion. Asterisks indicate significant differences between control and treatment groups $(P<0.001)$. The lowercase $\mathrm{y}$ and $\mathrm{z}$ denote significant differences in total protein $(P<0.05)$. Values are mean \pm SEs.

\begin{tabular}{|c|c|c|c|c|c|c|c|c|}
\hline \multirow[b]{3}{*}{ Variable } & \multicolumn{4}{|c|}{ Exposure time } & \multicolumn{4}{|c|}{ Postexposure time } \\
\hline & \multicolumn{2}{|c|}{$48 \mathrm{~h}$} & \multicolumn{2}{|c|}{$96 \mathrm{~h}$} & \multicolumn{2}{|c|}{$12 \mathrm{~h}$} & \multicolumn{2}{|c|}{$84 \mathrm{~h}$} \\
\hline & Control & Treated & Control & Treated & Control & Treated & Control & Treated \\
\hline $\mathrm{PO}_{2}$ & $11 \pm 2.4$ & $5 \pm 0 *$ & $12 \pm 5.2$ & $5 \pm 0 *$ & $8.4 \pm 1.5$ & $5.2 \pm 0.2^{*}$ & $9.17 \pm 1.9$ & $5 \pm 0 *$ \\
\hline $\mathrm{SO}_{2}$ & $12.4 \pm 4.2$ & $0^{*}$ & $13 \pm 10.06$ & $2.2 \pm 1.4^{*}$ & $6 \pm 2.5$ & $8.5 \pm 3.0$ & $10.25 \pm 2.6$ & $7 \pm 5.4$ \\
\hline $\mathrm{PCO}_{2}^{2}$ & $16.2 \pm 0.9$ & $18.7 \pm 3.6$ & $18.1 \pm 0.8$ & $15.8 \pm 1.5$ & $16.5 \pm 0.7$ & $13.9 \pm 0.9$ & $16.2 \pm 0.7$ & $15.0 \pm 0.9$ \\
\hline Total protein & $2.78 \pm 0.4$ & $2.48 \pm 0.28 \mathrm{y}$ & $3.28 \pm 0.1$ & $2.74 \pm 0.1 \mathrm{yz}$ & $3.48 \pm 0.3$ & $2.86 \pm 0.2 \mathrm{yz}$ & $3.39 \pm 0.2$ & $3.4 \pm 0.1 \mathrm{z}$ \\
\hline Lipase & $51.8 \pm 8.6$ & $29.3 \pm 13.4^{*}$ & $56.8 \pm 1.9$ & $35.8 \pm 8.7^{*}$ & $42.8 \pm 5.3$ & $32.3 \pm 5.0$ & $43.1 \pm 6.8$ & $32.6 \pm 6.5$ \\
\hline
\end{tabular}




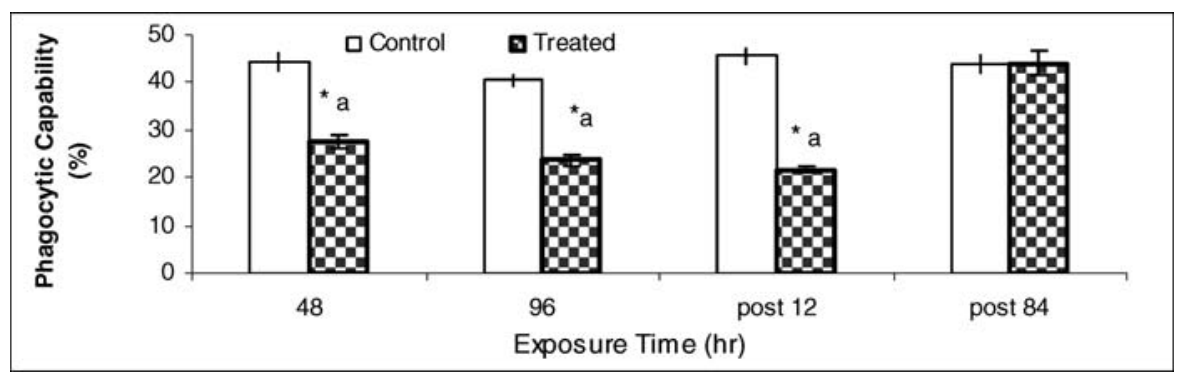

FIGURE 1.-Effects of hypoxia followed by reperfusion on phagocytic capability in peripheral blood leukocytes from control and hypoxia-exposed Nile tilapia $(n=5)$ at different time points. Asterisks represent significant differences in means between control and treated fish $(P<0.0001)$. The letter $a$ denotes a significant difference in phagocytic capability relative to that at $84 \mathrm{~h}$ reperfusion $(P<0.004)$. Error bars represent SEs.

reperfusion $(P<0.0001$; Figure 2). Its level continuously decreased during hypoxia and reperfusion, whereas it recovered to its control level at $84 \mathrm{~h}$ reperfusion $(P<0.02)$.

\section{Cytokine Expression}

The expression of TGF- $\beta$ mRNA by splenic mononuclear cells was significantly different during hypoxia and reperfusion compared with controls $(P<$ 0.0001 ; Figure 3 ). Its level constantly increased during $48 \mathrm{~h}$ and $96 \mathrm{~h}$ hypoxia and $12 \mathrm{~h}$ reperfusion, whereas it returned to the control level at $84 \mathrm{~h}$ reperfusion $(P<$ $0.03)$. Splenic mononuclear cell IL-1 $\beta$ transcription was significantly different from controls at $96 \mathrm{~h}$ hypoxia and $12 \mathrm{~h}$ reperfusion $(P=0.006$; Figure 4$)$. Its level significantly decreased the most at $12 \mathrm{~h}$ reperfusion, whereas it recovered to the control level at $84 \mathrm{~h}$ reperfusion $(P<0.002$; Figure 4$)$. In addition, the expression levels of both cytokines were compared with phagocytic capacity in this study via regression analysis (Figure 5). While the expression of TGF- $\beta$ was negatively correlated with phagocytic capacity $(y$ $\left.=-0.085 x+1.02 ; r^{2}=0.39 ; P=0.0017\right)$, that of IL- $1 \beta$ and phagocytosis, was positively correlated as expected $\left(y=4.08 x+1.32 ; r^{2}=0.989 ; P=0.005\right)$.

\section{Discussion}

Taken together, the results of this study are consistent with the hypothesis that environmental hypoxia triggers an overall downregulation of the immune response in fish. To evaluate immune function in the test fish, we used a series of assays of increasing specificity for the immune system, which allowed us to "cast a wider net" to detect changes in overall health while, at the same time, taking a narrow focus on specific immune function parameters. The broadest tier for evaluation was histopathology. While it did not detect any remarkable lesions that could be attributed to acute changes in DO, histopathology showed that the test fish had no predisposing adverse health conditions and that the lymphoid tissues were morphologically normal. While a relatively blunt instrument for evaluation of immune function, histopathology can provide a wealth of information at the tissue and cellular levels for comparatively little added cost. Especially in situations where the fish species being studied is not laboratory reared, systematic evaluation of major organ systems of both treated fish and controls is important.

The second tier in this study involved hematology, plasma chemistry, blood gases, and cortisol. Relative

TABLE 4.-Percentage of phagocytic cells in terms of the number of engulfed latex beads in peripheral blood leukocytes (PBL) of Nile tilapia $(n=5)$ subjected to $96 \mathrm{~h}$ of hypoxia followed by $84 \mathrm{~h}$ of reperfusion. Asterisks indicate significant differences between control and treatment group $(P<0.0001)$. The lowercase y and $\mathrm{z}$ denote significant differences. Within cell types $(P<$ $0.007, P<0.04$, and $P<0.05$ for PBL with 1,2 , and $>2$ beads, respectively). Values are means \pm SEs.

\begin{tabular}{|c|c|c|c|c|c|c|c|c|}
\hline \multirow[b]{3}{*}{ Phagocytic cells } & \multicolumn{4}{|c|}{ Exposure time } & \multicolumn{4}{|c|}{ Postexposure time } \\
\hline & \multicolumn{2}{|c|}{$48 \mathrm{~h}$} & \multicolumn{2}{|c|}{$96 \mathrm{~h}$} & \multicolumn{2}{|c|}{$12 \mathrm{~h}$} & \multicolumn{2}{|c|}{$84 \mathrm{~h}$} \\
\hline & Control & Treated & Control & Treated & Control & Treated & Control & Treated \\
\hline PBL with 1 bead & $24.6 \pm 1.8$ & $16.9 \pm 1.4 \mathrm{y}$ & $20.3 \pm 1.7$ & $15.4 \pm 2.9 \mathrm{y}$ & $22 \pm 1.8$ & $12.2 \pm 1.5 \mathrm{y}$ & $24.4 \pm 2.6$ & $24.7 \pm 1.9 \mathrm{z}$ \\
\hline PBL with 2 beads & $10.2 \pm 1.2$ & $7.3 \pm 1.2 \mathrm{yz}$ & $10.5 \pm 2.2$ & $4.3 \pm 1.3 \mathrm{y}$ & $15.5 \pm 2.4$ & $7.1 \pm 1.2 \mathrm{yz}$ & $12.2 \pm 1.7$ & $9.4 \pm 1.5 \mathrm{z}$ \\
\hline PBL with $>2$ beads & $9.7 \pm 1.8$ & $3.2 \pm 0.7 \mathrm{y}$ & $9.7 \pm 2.5$ & $4.1 \pm 0.6 \mathrm{y}$ & $9.1 \pm 1.1$ & $2.4 \pm 1.6 \mathrm{y}$ & $7.22 \pm 1.2$ & $9.8 \pm 1.7 \mathrm{z}$ \\
\hline
\end{tabular}




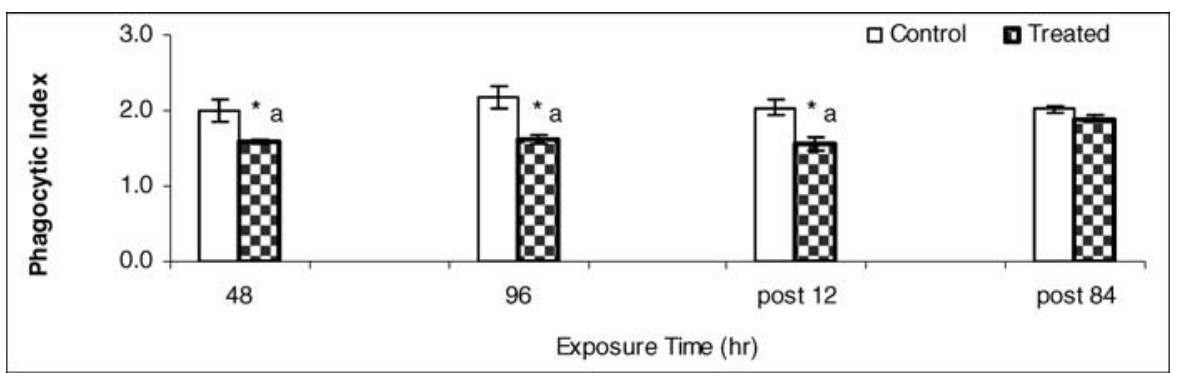

FIGURE 2.-Effects of hypoxia followed by reperfusion on the phagocytic index in peripheral blood leukocytes from control and hypoxia-exposed Nile tilapia $(n=5)$ at different time points. Asterisks represent significant differences in means between control and treated fish $(P<0.0001)$. The letter $a$ denotes a significant difference in the phagocytic index compared with its value at $84 \mathrm{~h}$ reperfusion $(P<0.01)$. Error bars represent SEs.

lymphopenia and neutrophilia were observed in fish subjected to hypoxia and reperfusion, whereas no significant changes in percent monocytes were found. At $84 \mathrm{~h}$ reperfusion, blood leukocyte values returned to initial control levels. These results are consistent with other reports that stress, regardless of its nature, can cause the characteristic changes in hematologic profiles, including neutrophilia and lymphopenia (Pickering and Pottinger 1985; Ellsaesser and Clem 1986; Ainsworth et al. 1991). Stress-induced neutrophilia is the result of decreased migration of neutrophils from the circulation into tissues and decreased "stickiness" of neutrophils to adhesion molecules, causing a shift from the marginated pool to the circulating neutrophil pool (Latimer et al. 2003).> The mechanism of stress-induced lymphopenia, on the other hand, is thought to be redistribution of recirculating lymphocytes, which are transiently sequestered in lymphoid tissues rather than entering the blood. Therefore, it is likely that the leukocyte changes in Nile tilapia are stereotypical responses to stress rather than unique effects of hypoxia, reperfusion, or both.

The lack of significant change in Hct in this study is consistent with Ellsaesser and Clem's (1986) report that Hct and actual erythrocyte numbers did not change under stresses such as transportation and handling. However, increased Hct is a commonly reported means of increasing blood oxygen carrying capacity in teleosts, some species apparently more sensitive than others. For example, European eels Anguilla anguilla exposed to hypoxic conditions for 2 weeks showed an increase in Hct and $\mathrm{Hb}$ concentration (Wood and Johansen 1973).> Under the conditions of our study, Nile tilapia did not appear to be sensitive in this regard, but may have developed an increased Hct if exposed to hypoxic conditions for weeks rather than days.

Plasma cortisol and glucose are considered primary and secondary responses to stress and are used to measure its severity and duration (Mazeaud et al. 1977/ 1977; Henrique et al. 1998). Unexpectedly in our study, no significant changes were found in plasma cortisol or glucose concentrations during hypoxia or reperfusion. This is consistent with a study of gilthead seabream in which acute hypoxia resulted in no changes in plasma glucose or cortisol concentrations (Henrique et al. 1998). However, our results are in contrast with recent reports on Nile tilapia that hypoxic stress causes increased plasma glucose. Acute hypoxia

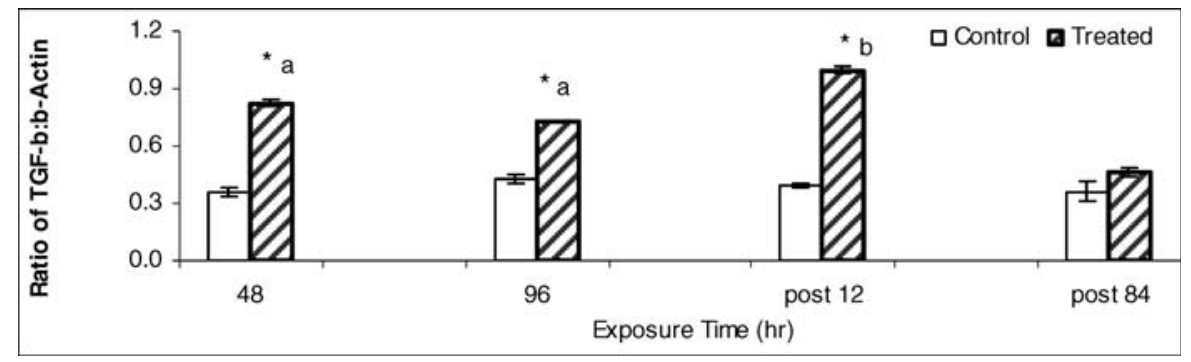

FIGURE 3.-The TGF- $\beta$ mRNA expression of splenic mononuclear cells from Nile tilapia $(n=5)$ subjected to 96 h hypoxia followed by $84 \mathrm{~h}$ reperfusion. Asterisks represent significant differences in means between control and treated fish $(P<0.0001)$. The letter $a$ denotes a significant difference in TGF- $\beta$ mRNA expression relative to that at $84 \mathrm{~h}$ reperfusion; the letter $b$ denotes significant difference in its expression between $48 \mathrm{~h}$ and $96 \mathrm{~h}$ hypoxia and $12 \mathrm{~h}$ reperfusion. Error bars represent SEs. 


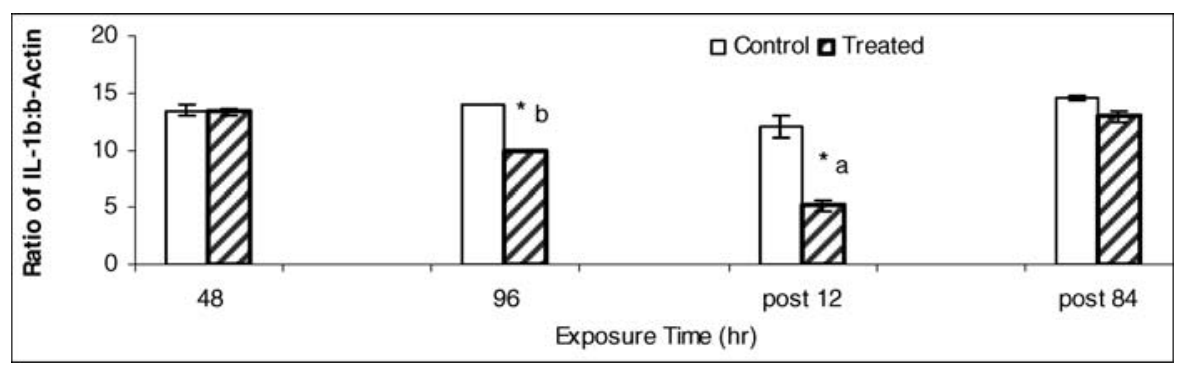

FIGURE 4.-The IL-1 $\beta$ mRNA expression of Nile tilapia $(n=5)$ splenic mononuclear cells subjected to $96 \mathrm{~h}$ hypoxia followed by $84 \mathrm{~h}$ reperfusion. Asterisks represent significant differences in means between control and treated fish $(P=0.006)$. The letter $a$ denotes significant difference in IL- $1 \beta$ mRNA expression relative to them at $48 \mathrm{~h}$ hypoxia and $84 \mathrm{~h}$ reperfusion; letter $b$ denotes significant difference between $96 \mathrm{~h}$ hypoxia and $12 \mathrm{~h}$ reperfusion. Error bars represent SEs.

( $1 \mathrm{mg} / \mathrm{L}$ for $24 \mathrm{~h}$ ) induced increased glucose in Nile tilapia (Evans et al. 2003), and 10-minair exposure caused increased glucose in two tilapia species (blue tilapia $O$. aureus and Mozambique tilapia O. mossambicus; Palti et al. 1999). The different results may be the result of differences in hypoxia exposure methods, duration of exposure, the different physiologic or acclimation status of the test fish, or differences in handling of the fish during the experiment.

The partial pressure of oxygen and oxygen saturation are measurements of the amount of free oxygen in the plasma and the percentage of $\mathrm{Hb}$ bound with oxygen, respectively, and can give us an idea of the blood's oxygen carrying capacity. As expected, Nile tilapia undergoing acute hypoxia had decreased values of $\mathrm{PO}_{2}$ and $\mathrm{SO}_{2}$ compared with controls (Table 3). This is consistent with other studies in which both $\mathrm{Po}_{2}$ and $\mathrm{So}_{2}$ were decreased in response to hypoxia in Nile tilapia (Fernandes and Rantin 1994) and rainbow trout (Thomas and Hughes 1982; Fernandes and Rantin 1994). The $\mathrm{So}_{2}$ appeared to recover during reoxygenation, but we do not know why $\mathrm{Po}_{2}$ remained decreased in the treated fish. The i-STAT instrument is seeing increased use for aquatic species, such as for blood gas analyses (Sladky et al. 2001). The reportable range for $\mathrm{Po}_{2}$ by the i-STAT is $5-800 \mathrm{~mm} \mathrm{Hg}$. However, validation of such convenient instruments will only be achieved over time and with increased numbers of reports. The interindividual variability was high with the $\mathrm{Po}_{2}$ readings, and blood samples must be handled carefully to maintain precision with blood oxygen measurements. Plasma $\mathrm{pH}, \mathrm{PCO}_{2}$, and $\mathrm{HCO}_{3}{ }^{-}$ values, however, were not significantly different from controls during hypoxia or reperfusion (data not shown). This result is contrary to a study with rainbow trout in which, at the early onset of hypoxia, respiratory alkalosis occurred as a result of a decrease in $\mathrm{PCO}_{2}$ that was followed by a continuous decrease in $\mathrm{HCO}_{3}^{-}$ concentration and increased lactate concentration (Lykkeboe and Weber 1978; Thomas and Hughes 1982). Again, this would suggest that Nile tilapia are, perhaps, less sensitive (i.e., better adapted physiologically than many species) to hypoxic conditions.

Low concentrations of total plasma protein (TP) in response to hypoxia and reperfusion was observed, except at $84 \mathrm{~h}$ reperfusion (Table 3). Its value decreased the most at $48 \mathrm{~h}$ hypoxia and returned to the control value at $84 \mathrm{~h}$ reperfusion. Whereas low TP

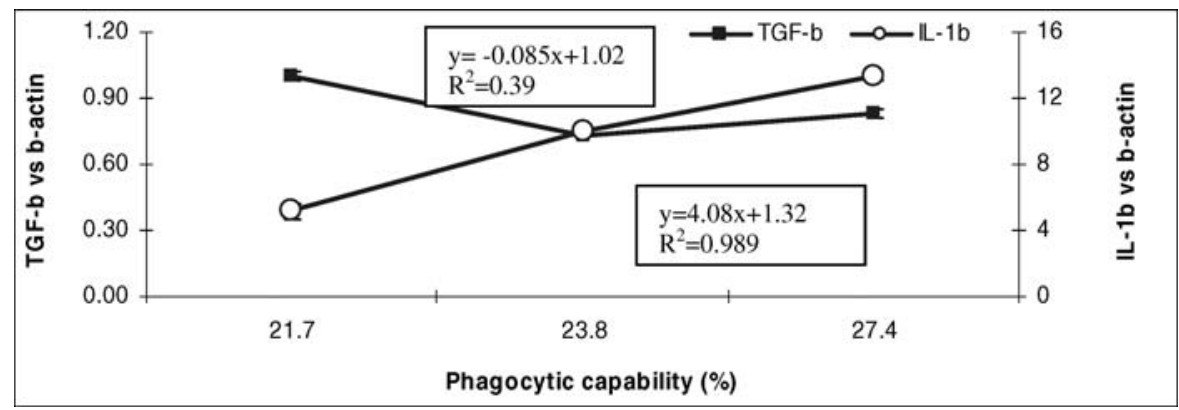

FIGURE 5.-Correlations between phagocytic capability and TGF- $\beta$ mRNA and IL- $1 \beta$ mRNA expression in Nile tilapia subjected to $96 \mathrm{~h}$ hypoxia followed by $84 \mathrm{~h}$ reperfusion. Error bars represent SEs. 
levels may be associated with disease states (Medemeyer et al. 1984), increased TP, globulins, and immunoglobulin $\mathrm{M}$ are considered to be related to effective innate immune responses in fish (Wiegertjes et al. 1996). Low TP may occur through a decrease in protein synthesis or increased protein catabolism to reduce energy utilization induced by low-oxygen stress (Mazeaud et al. 1977; Lutz and Nilsson 1997). A shutdown of protein production, then, may be considered a form of decompensation or unsuccessful adaptation resulting from the depletion of cellular energy stores in hypoxic states. Low plasma protein could be considered another indicator, albeit relatively nonspecific, of reduced immune function in fishes as a result of hypoxia.

Impaired lipid metabolism, including low cholesterol, has been correlated with reduced host resistance to pathogen invasion (Maita et al. 1998). In this study, plasma lipase in Nile tilapia continued to decrease in response to hypoxia compared with controls, but without changing during reperfusion, whereas there were no changes in cholesterol or triglyceride concentrations. This is consistent with a report that acute hypoxia induced no change in plasma total cholesterol in blue and Mozambique tilapia (Palti et al. 1999). In contrast, hypoxia induced significant increases in plasma cholesterol, triglycerides, and nonesterified fatty acids in a murine model (Raff et al. 2000). In our study, plasma electrolytes $\left(\mathrm{Na}^{+}, \mathrm{Cl}^{-}, \mathrm{Ca}, \mathrm{iCa}, \mathrm{K}, \mathrm{P}\right.$, and $\mathrm{Mg}$ ) were not affected by hypoxia or reperfusion. These findings are consistent with a study with rainbow trout in which acute hypoxia $(9.3 \mathrm{kPa})$ did not affect plasma $\mathrm{Na}^{+}, \mathrm{Cl}^{-}, \mathrm{iCa}$, or $\mathrm{K}$ (Kakizawa et al. 1997). It is apparent that plasma chemistry values in fish depend on severity and duration of hypoxia and reperfusion.

Phagocytosis is a primary defense against pathogens and is associated with increased or decreased phagocytic activity after nonspecific or specific stimulation (Michel and Hollebecq 1999). The common types of phagocytic cells in fishes, as in mammals, are the granulocytes and mononuclear phagocytes (Secombes and Fletcher 1992). In this study, we assessed phagocyte function by the ability of these cells to ingest opsonized beads. Both phagocytic capability and phagocytic index were significantly lower in response to acute hypoxia compared with control values. A similar impairment of phagocyte function was seen in oyster toadfish Opsanus tau collected from the polycyclic, aromatic, hydrocarbon-polluted Elizabeth River, Virginia (Seeley and Weeks-Perkins 1991). In that study, macrophages showed impaired activity along a pollutant concentration gradient. However, in our study, phagocytosis was impaired only temporarily during acute hypoxia, since normoxia allowed recovery to original values by $84 \mathrm{~h}$ reperfusion. Nonetheless, even with the apparent recovery of phagocytic function upon restoration of oxygen, it is likely that hypoxia of this duration would make fish more susceptible to microbial pathogens.

Immunological responses are dependent on the actions of various agents, their interactions with each other or immunocompetent cells, and other endogenous factors such as cytokines (Harris and Bird 2000). In our study, we demonstrated that cytokine transcription is altered in Nile tilapia by hypoxia and reperfusion. Whether TGF- $\beta$ is anti- or proinflammatory depends on its concentration, the state of differentiation of the target cells, and its interaction with other inflammatory mediators (McCartney-Francis and Wahl 1994). When considered with the other findings in our study, it is likely that TGF- $\beta$ had a negative impact on immune function. The significant increase in TGF- $\beta$ mRNA in splenic mononuclear cells was negatively correlated with phagocytosis. Based on known TGF- $\beta$ immunosuppressive effects on macrophage activation, this negative correlation is expected. This is also consistent with the inverse relationship between TGF- $\beta$ mRNA and bactericidal activity in triamcinolone-treated hybrid striped bass (Harms et al. 2000). The downregulation of IL-1 $\beta$ transcription observed in this study during hypoxia and reperfusion also correlated well with reduced phagocytic activity of peripheral blood leukocytes. Although IL-1 functions are characterized in only a few fish species, these results were expected based on the proinflammatory activity of IL-1 $\beta$ in mammals (Dinarello 1991). When tissue oxygen tension becomes too low, HIF- $1 \alpha$ is stabilized, resulting in impaired phagocyte functions, decreased T-helper-1 (Th1) cytokine expression, and a shift from Th1 to Th2 immune responses (Sitkovsky and Lukashev 2005). Interestingly, since the Nile tilapia in our study did not have elevated plasma cortisol levels, it seems that these cytokine changes are mediated more through HIF-1 $\alpha$ than any membranestabilizing effects of cortisol.

In this study, a three-tiered approach that included classical cellular immunoassays and cytokine production improved our understanding of the mechanisms of hypoxic changes in the affected animals. The altered cytokine expression and inhibited phagocytosis accompanied by changes in hematology and plasma chemistry suggest that acute hypoxia and reperfusion induce considerable physiological stress in fishes. This may imbalance Th1 or Th2 homeostasis, leading to inhibition of Th1 responses and reduced resistance to opportunistic or invasive pathogens. In further studies, the combined effects of hypoxia and other environmental stressors should be investigated using these 
assays to better understand the health status of aquatic habitats impacted by multiple stressors.

\section{Acknowledgments}

This work was supported by a grant from the North Carolina Department of Environment and Natural Resources (Projects EW 20002, 20000) and funds from the North Carolina Department of Health and Human Services, Centers for Disease Control (Project 01081-01). The authors acknowledge Dennis Delong, NCSU Extension Aquaculture Specialist, for providing Nile tilapia used in the experiment and Ed Noga for helpful comments on the manuscript.

\section{References}

Adams, S. A., K. L. Shepard, M. S. Greeley, Jr., B. D. Jimenez, M. G. Ryon, L. R. Shugart, and J. F. McCarthy. 1989. The use of bioindicators for assessing the effects of pollutant stress on fish. Marine Environmental Research 28:459-464.

Ainsworth, A. J., C. Dexiang, and P. R. Waterstrat. 1991. Changes in peripheral blood leukocyte percentages and function of neutrophils in stressed channel catfish. Journal of Aquatic Animal Health 3:41-47.

Anderson, D. P., and M. G. Zeeman. 1995. Immunotoxicology in fish. Pages 371-404 in G. Rand, editor. Fundamentals of aquatic toxicology: effects, environmental fate, and risk assessment. Taylor \& Francis, Washington, D.C.

Basile, D. P., D. R. Martin, and M. R. Hammerman. 1998. Extracellular matrix-related genes in kidney after ischemic injury: potential role for TGF-beta in repair. American Journal of Physiology 275:F894-F903.

Blazer, V. S., J. H. Lilley, W. B. Schill, Y. Kiryu, C. L. Densmore, V. Panyawachira, and S. Chinabut. 2002. Aphanomyces invadans in Atlantic menhaden along the East Coast of the United States. Journal of Aquatic Animal Health 14:1-10.

Bly, J. E., S. M. Quiniou, and L. W. Clem. 1997. Environmental effects on fish immune mechanisms. Fish Vaccinology Development in Biological Standardization 90:33-43.

Boleza, K. A., L. E. Burnett, and K. G. Burnett. 2001. Hypercapnic hypoxia compromises bactericidal activity of fish anterior kidney cells against opportunistic environmental pathogens. Journal of Fish and Shellfish Immunology 11:593-610.

Boyd, C. E. 1990. Water quality in ponds for aquaculture. Alabama Agricultural Experiment Station, Auburn.

Bunch, E. C., and I. Bejerano. 1997. The effect of environmental factors on the susceptibility of hybrid tilapia Oreochromis niloticus $\times$ Oreochromis aures to streptococcosis. Israel Journal of Aquaculture 49:67-76.

Cecchini, S., and M. Saroglia. 2002. Antibody response in sea bass (Dicentrarchus labrax L.) in relation to water temperature and oxygenation. Aquaculture Research 33:607-613.

Chen, H. 2003. Studies on cell injury induced by hypoxiareoxygenation and oxidized low density lipoprotein.
Doctoral dissertation. Uppsala University, Uppsala, Sweden.

Cuesta, A., M. Angeles Esteban, and J. Meseguer. 2003. Effects of different stressor agents on gilthead seabream natural cytotoxic activity. Journal of Fish and Shellfish Immunology 15:433-441.

Dhandapani, K. M., and D. W. Brann. 2003. Transforming growth factor-beta: a neuroprotective factor in cerebral ischemia. Cell Biochemistry and Biophysics 39:13-22.

Dinarello, C. A. 1991. Interleukine-1. Pages 47-82 in A. W. Thomas, editor. The cytokine handbook. Academic Press, London.

Dykstra, M. J. 2000. Pfiesteria piscicida and ulcerative mycosis of Atlantic menhaden: current status of understanding. Journal of Aquatic Animal Health 12:18-25.

Ellsaesser, C. F., and L. W. Clem. 1986. Haematological and immunological changes in channel catfish stressed by handling and transport. Journal of Fish Biology 28:511521.

Engelsma, M. Y., R. J. Stet, and H. Schipper. and B. M. Verburg-van Kemenade. 2001. Regulation of interleukin 1 beta RNA expression in the common carp, Cyprinus carpio L. Developmental and Comparative Immunology 25(3): 195-203.

Evans, J. J., C. A. Shoemaker, and P. H. Klesius. 2003. Effects of sublethal dissolved oxygen stress on blood glucose and susceptibility to Streptococcus agalactiae in Nile tilapia Oreochromis niloticus. Journal of Aquatic Animal Health 15:202-208.

Fernandes, M. N., and F. T. Rantin. 1994. Relationship between oxygen availability and metabolic cost of breathing in Nile tilapia (Oreochromis niloticus): aquacultural consequences. Aquaculture 127:339-346.

Fukuda, Y., M. Maita, K. Satoh, and N. Okamoto. 1997. Influence of dissolved oxygen concentration on the mortality of yellowtail experimentally infected with Enterococcus seriolicida. Fish Pathology 32:129-130.

Harms, C. A., C. Ottinger, and S. Kennedy-Stoskopf. 2000. Correlation of transforming growth factor- $\beta$ messenger RNA (TGF- $\beta$ mRNA) expression with cellular immunoassays in triamcinolone-treated captive hybrid striped bass. Journal of Aquatic Animal Health 12:9-17.

Harper, D. E., Jr., L. D. McKinney, R. R. Salzer, and R. J. Case. 1981. The occurrence of hypoxic bottom water off the upper Texas coast and its effect on benthic biota. Contributions in Marine Science 24:53-79.

Harris, J., and D. J. Bird. 2000. Modulation of the fish immune system by hormones. Veterinary Immunology and Immunopathology 77:163-176.

Hempel, S. L., M. M. Monick, and G. W. Hunninghake. 1996. Effect of hypoxia on release of IL-1 and TNF by human alveolar macrophages. American Journal of Respiratory Cell and Molecular Biology 14:170-176.

Henrique, M. M. F., E. F. Gomes, M. F. Gouillou-Coustans, A. Oliva-Teles, and S. J. Davies. 1998. Influence of supplementation of practical diets with vitamin $\mathrm{C}$ on growth and response to hypoxic stress of seabream, Sparus aurata. Aquaculture 161:415-426.

Hurty, C. A., D. C. Brazik, J. M. Law, K. Sakamoto, and G. A. Lewbart. 2002. Evaluation of the tissue reactions in 
the skin and body wall of koi (Cyprinus carpio) to five suture materials. Veterinary Record 151:324-328.

IUBMB (International Union of Biochemistry and Molecular Biology). 1992. Enzyme nomenclature 1992. Academic Press, San Diego, California.

Jordan, J. E., Z. Q. Zhao, and J. Vinten-Johansen. 1999. The role of neutrophils in myocardial ischemia-reperfusion injury. Cardiovascular Research 43:860-878.

Kakizawa, S., A. Ishimatsu, T. Takeda, T. Kaneko, and T. Hirano. 1997. Possible involvement of somatolactin in the regulation of plasma bicarbonate for the compensation of acidosis in rainbow trout. Journal of Experimental Biology 200:2675-2683.

Kiryu, Y., J. D. Shields, W. K. Vogelbein, D. E. Zwerner, H. Kator, and V. S. Blazer. 2002. Induction of skin ulcers in Atlantic menhaden by injection and aqueous exposure to the zoospores of Aphanomyces invadans. Journal of Aquatic Animal Health 14:11-24.

Latimer, K. S., and K. W. Prasse. 2003. Leukocytes. Pages 46-79 in K. S. Latimer, E. A. Mahaffey, and K. W. Prasse. Duncan and Prasse's Veterinary laboratory medicine: clinical pathology, 4th edition. Iowa State Press, Ames.

Lehmann, D. W., J. F. Levine, and J. M. Law. 2005. Design and use of a highly responsive and rigidly controllable hypoxia exposure system. Pages 547-555 in G. K. Ostrander, editor. Techniques in aquatic toxicology, volume 2. Taylor and Francis, Boca Raton, Florida.

Lutz, P. L., and G. E. Nilsson. 1997. Contrasting strategies for anoxic brain survival: glycolysis up or down. Journal of Experimental Biology 200:411-419.

Lykkeboe, G., and R. E. Weber. 1978. Changes in respiratory properties of the blood in the carp, Cyprinus carpio, induced by diural variation in ambient oxygen tension. Journal of Comparative Physiology B 128:117-125.

Maita, M., K. Satoh, Y. Fukuda, H. Lee, J. R. Winton, and N. Okamoto. 1998. Correlation between plasma component levels of cultured fish and resistance to bacterial infection. Fish Pathology 33:129-133.

Malone, T. C. 1991. Modern and ancient continental shelf anoxia. Geological Society, London.

Mazeaud, M., F. Mazeaud, and E. Donaldson. 1977. Primary and secondary effects of stress in fish: some new data with a general review. Transactions of the American Fisheries Society 106:201-212.

McCartney-Francis, N. L., and S. M. Wahl. 1994. Transforming growth factor- $\beta$ : a matter of life and death. Journal of Leukocyte Biology 55:401-409.

Medemeyer, G., D. McLeay, and C. Goodyear. 1984. Assessing the tolerance of fish and fish populations to environmental stress: the problems and methods of monitoring. Pages 163-196 in V. Cairns, P. Hodson, and J. Nriagu, editors. Contaminant effects on fisheries, volume 16. Wiley, New York.

Michel, C., and M. G. Hollebecq. 1999. Independence of phagocytic activity and susceptibility to furunculosis in families of rainbow trout (Oncorhynchus mykiss) genetically selected for differential resistance. Journal of Fish and Shellfish Immunology 9:81-93.

Michiels, C. 2004. Review: physiological and pathological responses to hypoxia. American Journal of Pathology 164:1875-1882.
NCDENR (North Carolina Department of Environment Health and Natural Resources). 1997. Division of Water Quality annual report of fish kill events. NCDENR, Raleigh.

NCDENR (North Carolina Department of Environment Health and Natural Resources). 2000. Atlantic menhaden lesion prevalence study for Neuse and Pamlico River estuaries. NCDENR, Raleigh.

Noga, E. J. 2000. Skin ulcers in fish: Pfiesteria and other etiologies. Toxicologic Pathology 28:807-823.

Noga, E. J., L. Khoo, J. B. Stevens, Z. Fan, and J. M. Burkholder. 1996. Novel toxic dinoflagellate causes epidemic disease in estuarine fish. Marine Pollution Bulletin 2:219-224.

Ortuno, J., M. A. Esteban, and J. Meseguer. 2002. Lack of effect of combining different stressors on innate immune responses of seabream. Veterinary Immunology and Immunopathology 84:17-27.

Paerl, H. W., J. D. Bales, L. W. Ausley, C. P. Buzzelli, L. B. Crowder, L. A. Eby, J. M. Fear, M. Go, B. L. Peierls, T. L. Richardson, and J. S. Ramus. 2001. Ecosystem impacts of three sequential hurricanes (Dennis, Floyd, and Irene) on the United States' largest lagoonal estuary, Pamlico Sound, NC. Proceedings of the National Academy of Sciences of the USA 98:5655-5660.

Palti, Y., S. Tinman, A. Cnaani, Y. Avidar, M. Ron, and G. Hulata. 1999. Comparative study of biochemical and nonspecific immunological parameters in two tilapia species (Oreochromis aureus and O. mossambicus). Israel Journal of Aquaculture 51:148-156.

Pickering, A. D., and T. G. Pottinger. 1985. Cortisol can increase the susceptibility of brown trout, Salmo trutta L., to disease without reducing the white blood cell count. Journal of Fish Biology 27:611-619.

Raff, H., E. D. Bruder, B. M. Jankowski, and T. L. Goodfriend. 2000. Neonatal hypoxic hyperlipidemia in the rat: effects on aldosterone and corticosterone synthesis in vitro. American Journal of PhysiologyRegulatory, Integrative and Comparative Physiology 278:R663-R668.

Rosenwasser, L. J. 1998. Biologic activities of IL-1 and its role in human disease. Journal of Allergy and Clinical Immunology 102:344-350.

SAS. 2003. SAS users guide: statistics. SAS Institute, Cary, North Carolina.

Secombes, C. J., S. Bird, C. Cunningham, and J. Zou. 1999. Interleukin-1 in fish. Journal of Fish and Shellfish Immunology 9:335-343.

Secombes, C. J., and T. C. Fletcher. 1992. The role of phagocytes in the protective mechanisms of fish. Annual Review of Fish Diseases 2:53-71.

Seeley, K. R., and B. A. Weeks-Perkins. 1991. Altered phagocytic activity of macrophages in oyster toadfish from a highly polluted subestuary. Journal of Aquatic Animal Health 3:224-227.

Sitkovsky, M., and D. Lukashev. 2005. Regulation of immune cells by local tissue oxygen tension: HIF-1alpha and adenosine receptors. Nature Reviews in Immunology $5: 712-721$.

Sladky, K. K., C. R. Swanson, M. K. Stoskopf, M. R. Loomis, and G. A. Lewbart. 2001. Comparative efficacy of tricaine methanesulfonate and clove oil for use as 
anesthetics in red pacu (Piaractus brachypomus). American Journal of Veterinary Research 62:337-342.

Thomas, S., and G. M. Hughes. 1982. A study of the effects of hypoxia on acid-base status of rainbow trout blood using an extracorporeal blood circulation. Respiration Physiology 49:371-382.

Thuvander, A., L. Norrgren, and C. Fossum. 1987. Phagocytic cells in blood from rainbow trout, Salmo gairdneri (Richardson), characterized by flow cytometry and electron microscopy. Journal of Fish Biology 31:197208.

Turner, R. E., and R. L. Allen. 1972. Bottom water oxygen concentration in the Mississippi River delta bight. Contributions in Marine Science 25:161-172.

Turner, R. E., W. W. Schroeder, and W. J. Wiseman, Jr. 1987. The role of stratification in the deoxygenation of Mobile Bay and adjacent shelf bottom waters. Estuaries 10:1319.

Verdegem, M. C. J., A. D. Hilbrands, and J. H. Boon. 1997. Influence of salinity and dietary composition on blood parameter values of hybrid tilapia, Oreochromis niloticus L. $\times$ O. mossambicus P. Aquaculture Research 28:453459.

Wiegertjes, G. F., R. J. M. Stet, and H. K. Parmentier. and W. B. van Muiswinkel. 1996. Immunogenetics of disease resistance in fish: a comparative approach. Development and Comparative Immunology 20:365-381.

Woo, P. T. K. 2003. Cryptobia (Trypanoplasma salmositica) and salmonid cryptobiosis. Journal of Fish Diseases 26:627-646.

Wood, S. C., and K. Johansen. 1973. Organic phosphate metabolism in nucleated red cells. Influence of hypoxia on eel $\mathrm{HbO}$ affinity. Netherland Journal of Sea Research 7:328-338.

Wu, R. S. S. 2002. Hypoxia: from molecular responses to ecosystem responses. Marine Pollution Bulletin 45:3545.

Wu, R. S. S., B. S. Zhou, D. J. Randall, N. Y. S. Woo, and P. K. S. Lam. 2003. Aquatic hypoxia is an endocrine disruptor and impairs fish reproduction. Environmental Science and Technology 37:1137-1141.

Yellon, D. M., and G. F. Baxter. 1999. Reperfusion injury revisited: is there a role for growth factor signaling in limiting lethal reperfusion injury? Trends in Cardiovascular Medicine 9:245-249.

Zhang, H. Y., and S. H. Phan. 1999. Inhibition of myofibroblast apoptosis by transforming growth factor beta (1). American Journal of Respiratory Cell and Molecular Biology 21:658-665.

Zou, J., P. S. Grabowski, C. Cunningham, and C. J. Secombes. 1999. Molecular cloning of interleukin $1 \beta$ from rainbow trout Oncorhynchus mykiss reveals no evidence of an ice cut site. Cytokine 11(8):552-560.

Zuckerman, S. H., C. Panousis, and G. Evans. 2001. TGF-beta reduced binding of high-density lipoproteins in murine macrophages and macrophage-derived foam cells. Atherosclerosis 155:79-85. 